Review Article

\title{
(Mesenchymal) Stem Cell-Based Therapy in Cisplatin-Induced Acute Kidney Injury Animal Model: Risk of Immunogenicity and Tumorigenicity
}

\author{
Ž. Večerićc-Haler, ${ }^{1}$ A. Cerar, ${ }^{2}$ and M. Perše ${ }^{2}$ \\ ${ }^{1}$ Department of Nephrology, University Medical Centre Ljubljana, SI-1000 Ljubljana, Slovenia \\ ${ }^{2}$ Institute of Pathology, Medical Experimental Centre, Faculty of Medicine, University of Ljubljana, Zaloška 4, \\ SI-1105 Ljubljana, Slovenia
}

Correspondence should be addressed to M. Perše; martina.perse@mf.uni-lj.si

Received 25 August 2017; Accepted 12 November 2017; Published 12 December 2017

Academic Editor: Luca Vanella

Copyright (c) 2017 Ž. Večerić-Haler et al. This is an open access article distributed under the Creative Commons Attribution License, which permits unrestricted use, distribution, and reproduction in any medium, provided the original work is properly cited.

\begin{abstract}
Pathogenesis of AKI is complex and involves both local events in the kidney as well as systemic effects in the body that are interconnected and interdependent. Despite intensive investigations there is still no pharmacological agent that could provide complete protection against cisplatin nephrotoxicity. In the last decade mesenchymal stem cells (MSCs) have been proposed as a potentially useful therapeutic strategy in various diseases, including acute kidney injury. Although MSCs have potent immunosuppressive properties, animal studies also suggest that transplanted MSCs may elicit immune response. Interestingly, tumorigenicity of transplanted MSCs in animal studies has been rarely studied. Since the risk of tumorigenicity of particular therapy as well as the immune response to solid or cell grafts is a major issue in clinical trials, the aim of the present paper is to critically summarize the results of MSC transplantation on animal models of AKI, particularly cisplatin-induced animal models, and to expose results and main concerns about immunogenicity and tumorigenicity of transplanted MSCs, two important issues that need to be addressed in future studies.
\end{abstract}

\section{Introduction}

Today, mesenchymal stem cell (MSC) therapy is recognized as a potentially useful innovative therapeutic strategy in various diseases [1]. Increasing number of experimental studies demonstrated beneficial effects of MSCs also in acute kidney injury (AKI) [2]. The pathophysiology of AKI is very complex and involves tubular and vascular cell damage and an intense inflammatory reaction. Current therapies of AKI mainly include supportive care, including renal replacement therapy. Despite these therapies, the five-year mortality rate for patients with AKI remains $>50 \%$. Hence, new therapeutic interventions and strategies for improving survival outcome for patients with AKI are needed. Stem cell-based therapy has gained great interest in AKI treatment over the years [2]. Recent studies have focused on the clinical efficacy of MSC transplantation [3]. However, in clinical trials, the immune response to allogeneic solid or cell grafts has always been a major issue $[4,5]$. Although allogeneic MSCs have potent immunosuppressive properties, animal studies also suggest that they may elicit a weak allogeneic immune response [6].

Thus, the aim of the present paper is to critically summarize the results of MSC transplantation in animal models of AKI, particularly in cisplatin-induced animal models, and to expose important issues that need to be addressed in future studies. We have restricted our investigation on a cisplatin animal model, because it has specific characteristics that might have significant effect on short/long-term MSC studies.

To get insight into the reported side effects or risk factors of stem cell-based therapy in a cisplatin animal model, we conducted a PubMed search using keywords "cisplatin kidney and stem cells" and got 111 publications 
(July, 2017). Among them, 40 publications investigated the effects of stem cells on a cisplatin animal model and are shown in Tables 1 and 2 .

Tables 1 and 2 show the source and type of stem cells used, immune state of the animals, duration of the studies, and potential short/long-term risk effects of stem cell transplantation, delivery route, and so on.

1.1. Important Factors to Consider before Conclusion Can Be Made. Although most of the studies using the cisplatin animal model reported that MSC transplantation ameliorates $\mathrm{AKI}$, conclusions about the effectiveness and safety of MSCs must not be made before below stated factors are taken into consideration:

(1) Characteristics of cisplatin animal models

(2) Reliability of tracking the injected cells

(3) MSCs and risk of immune rejection

(4) MSCs and risk of tumorigenicity (duration of the study: most studies ended within a week, only few were performed to investigate potential side effects (8 weeks), but on very small number of animals $(n=3))$

\section{Characteristics of Cisplatin Animal Models}

The cisplatin model has its own characteristics. It is important to take into consideration the dose used as well as its immunosuppressive and carcinogenic effects. When neprotoxic dose of cisplatin is used, kidney dysfunction develops in 2-5 days, reaching peak at 4-7 days and then progressively recovers (blood urea nitrogen/serum creatinine (BUN/Cr) reach the baseline levels). When lethal dose of cisplatin is used (Table 3), self-recovery is less likely. However, with the higher doses of cisplatin, survival time of animals markedly decreases [54]. Importantly, high-nephrotoxic doses of cisplatin in rodents lead to systemic side effects, such as body weight loss and mortality. Cisplatin usually causes diarrhea in all animals, a significant decrease in both the lymphocytes (65\% decrease) and granulocytes (45\% decrease) in the bone marrow, decrease in circulating peripheral white blood count (WBC) [49], massive necrotic changes in the kidney, injuries in the gastrointestinal tract, testis, bone marrow [44], and the lymph tissue [55]. Cisplatin is also carcinogenic and can cause lung tumors in rodents [56].

\section{Reliability of Tracking the Injected Cells}

Most of the studies used labeling to check or confirm the presence of injected cells in kidneys and/or other organs (see Tables 1 and 2). It was reported that labeled cells (PKH26, GFP, and DIO) were mostly detected in the lungs, much less in the liver and in the kidneys [8, 10, 14, 18, 20, $22,23,25]$. Cheng et al. studied biodistribution and found that one hour after iv injection of syngeneic MSCs most of the radiolabeled (or GFP labeled) cells were trapped in the lungs $(62 \%)$, followed by liver $(12.5 \%)$, spleen $(11.4 \%)$, and kidneys (5.4\%), but 7 days after injection no signs of MSCs in any organ was found [36]. Studies using GFP labeling reported disappearance of $\mathrm{GFP}^{+}$cells in the kidney 4 days after injection [22, 31], while studies that used PKH26 [12, 33] or CM-Dil [13] labeling reported presence of positive cells in the kidney until the end of their study, that is, 2-4wks. Nevertheless, the fact that injected MSCs are mostly trapped in the lungs and cleared without any engraftment in kidney raise questions regarding their pathophysiologic mechanisms, as well as possibility of their potential rejection by the host's immune system.

\section{MSCs and Risk of Immune Rejection}

4.1. Can Xenogenic or Allogeneic MSCs Survive in Immunocompetent Environment? Human MSCs express specific membrane antigens (CD73, CD90, and CD105) and intermediate levels of major histocompatibility complex (MHC) class I molecules, while, in a naive state, they do not express MHC class II and the costimulatory molecules CD80 (B7-1), CD86 (B7-2), CD40, or CD40L [57]. They should therefore be recognized by alloreactive $\mathrm{T}$ cells, but numerous in vitro studies have shown that undifferentiated and differentiated human MSCs escape recognition by alloreactive $\mathrm{T}$ cells, escape lysis by cytotoxic $\mathrm{T}$ cells and natural killer (NK) cells, and inhibit mixed lymphocyte cultures (MLC), [57-59], suggesting that MSCs may thereby circumvent rejection and can thus be transplantable between $\mathrm{MCH}$-incompatible individuals without the need for host immunosuppression. Furthermore, the observation that MSCs are immunoprivileged and display immunosuppressive characteristics [60] suggest their therapeutic value in allogeneic transplantation to prevent graft rejection and to prevent/treat graft versus host disease.

Numerous experimental studies have reported that transplantation of allogeneic or even xenogeneic MSCs into immunocompetent animals without the use of immunosuppressants resulted in an improvement (reviewed in Lin et al. [61]) of a wide range of diseases, including cisplatininduced AKI, suggesting that hMSCs are immunotolerant. However, although MSCs seem to be transplantable across allogeneic or even xenogenic barriers, some animal studies have clearly shown that the cellular and humoral responses against the xenogenic MSCs in an immunocompetent recipient can develop (some example are shown in Table 4). Results also show that allogeneic MSCs are not intrinsically immunoprivileged but under appropriate conditions induce T cell response resulting in rejection of an allogeneic stem cell graft [65].

4.2. MSCs Mechanism and Risk of Immune Rejection. Despite evidence for the therapeutic potential of MSCs, the mechanisms underlying the improvement in kidney function and structure remain unclear. In the past, studies have reported that injected exogenous MSCs can home into injured tubules. Consequently, it has been proposed that the ability of MSCs to transdifferentiate explains their protective effects [25]. However, if the cells act by engrafting the tubules, then either they will need to be autollogous (host-derived to 


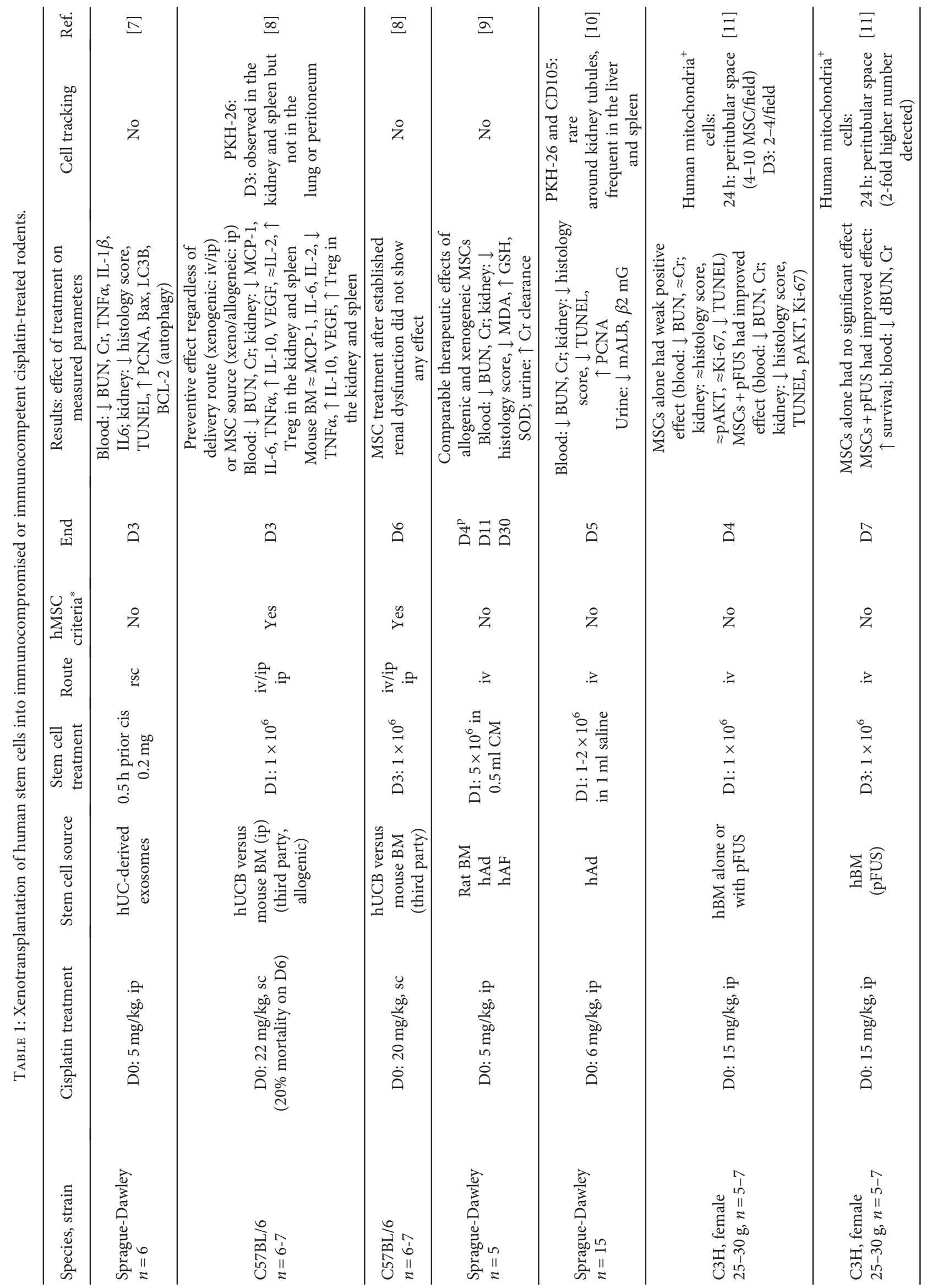




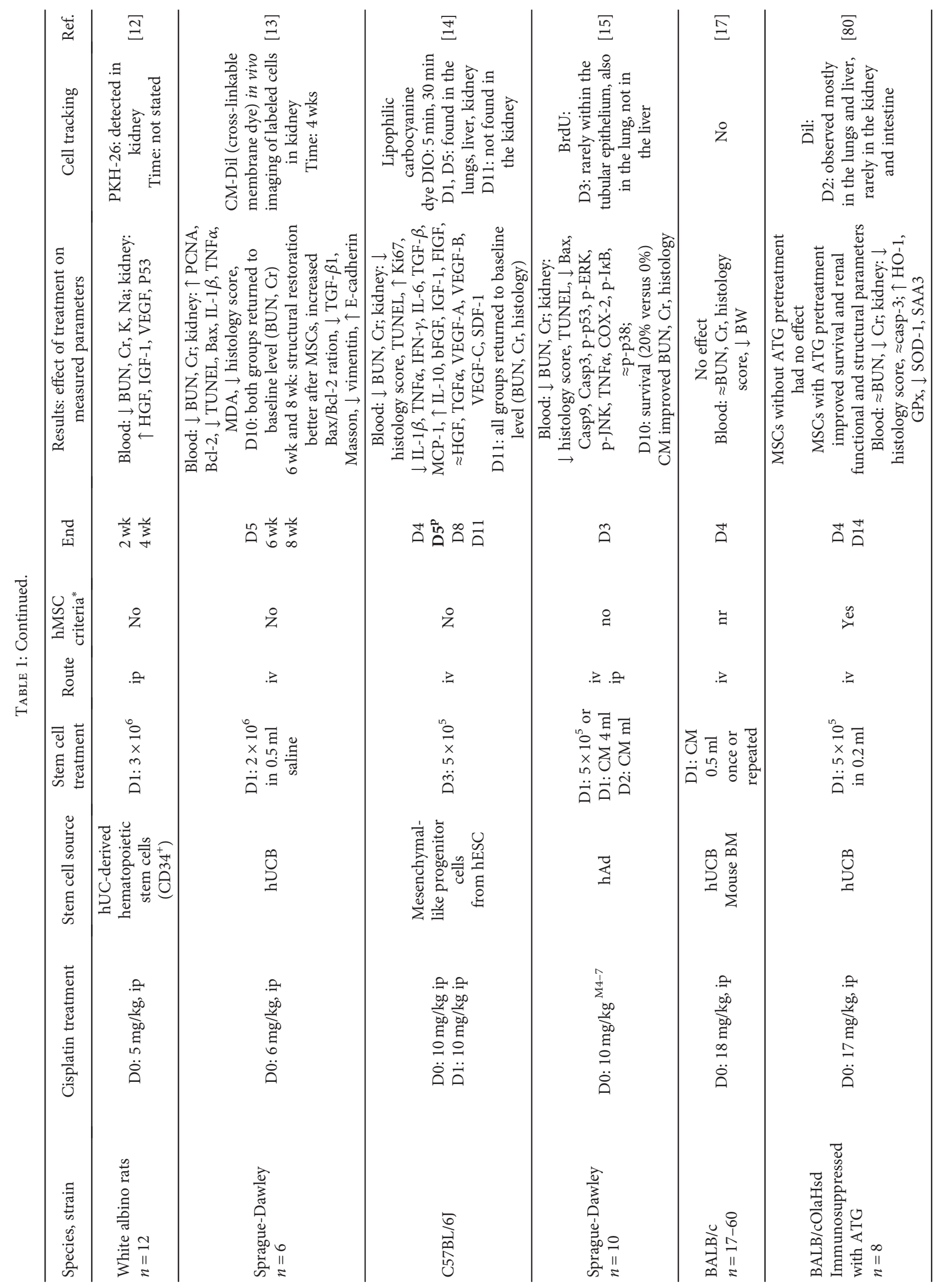




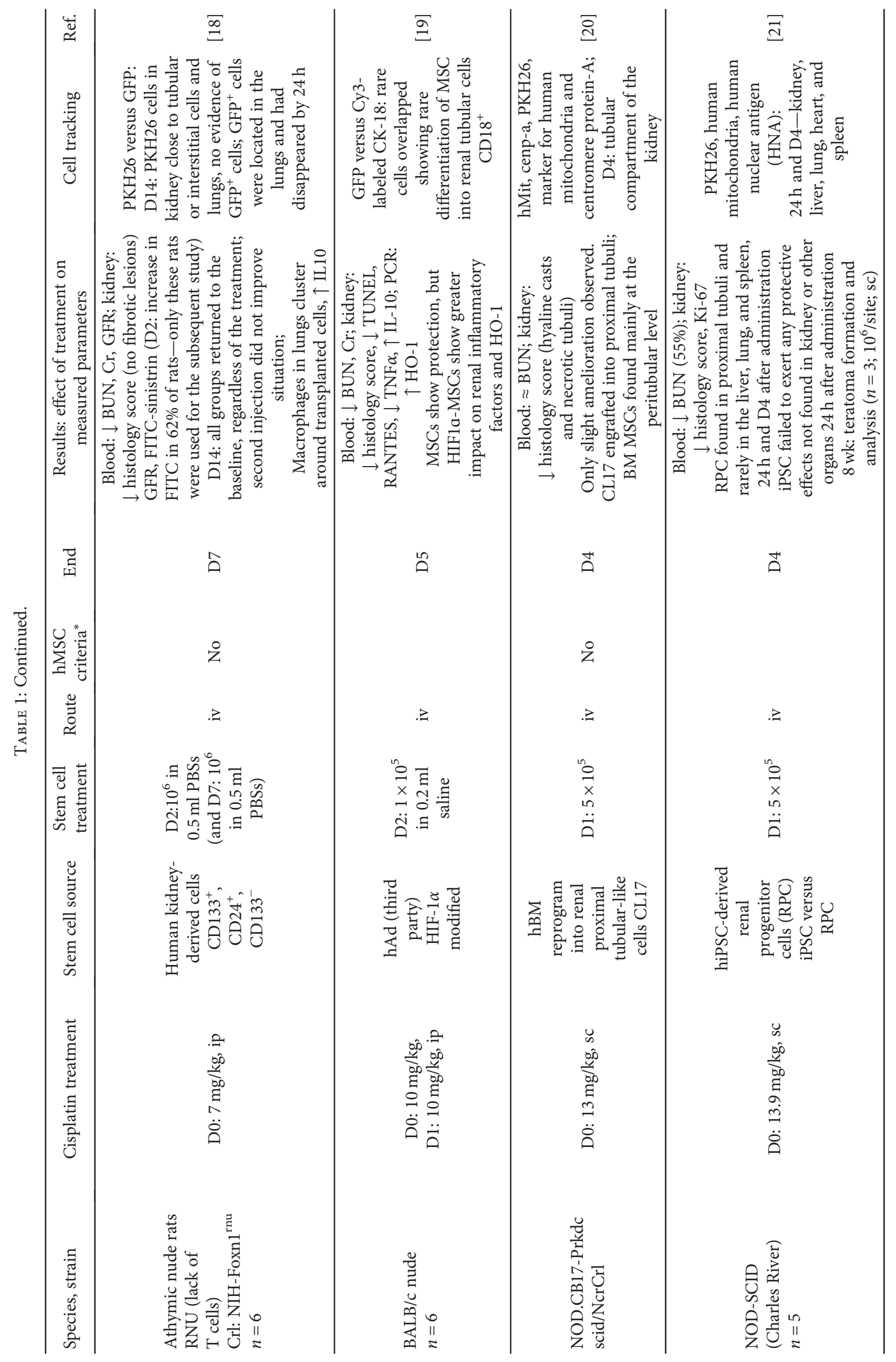




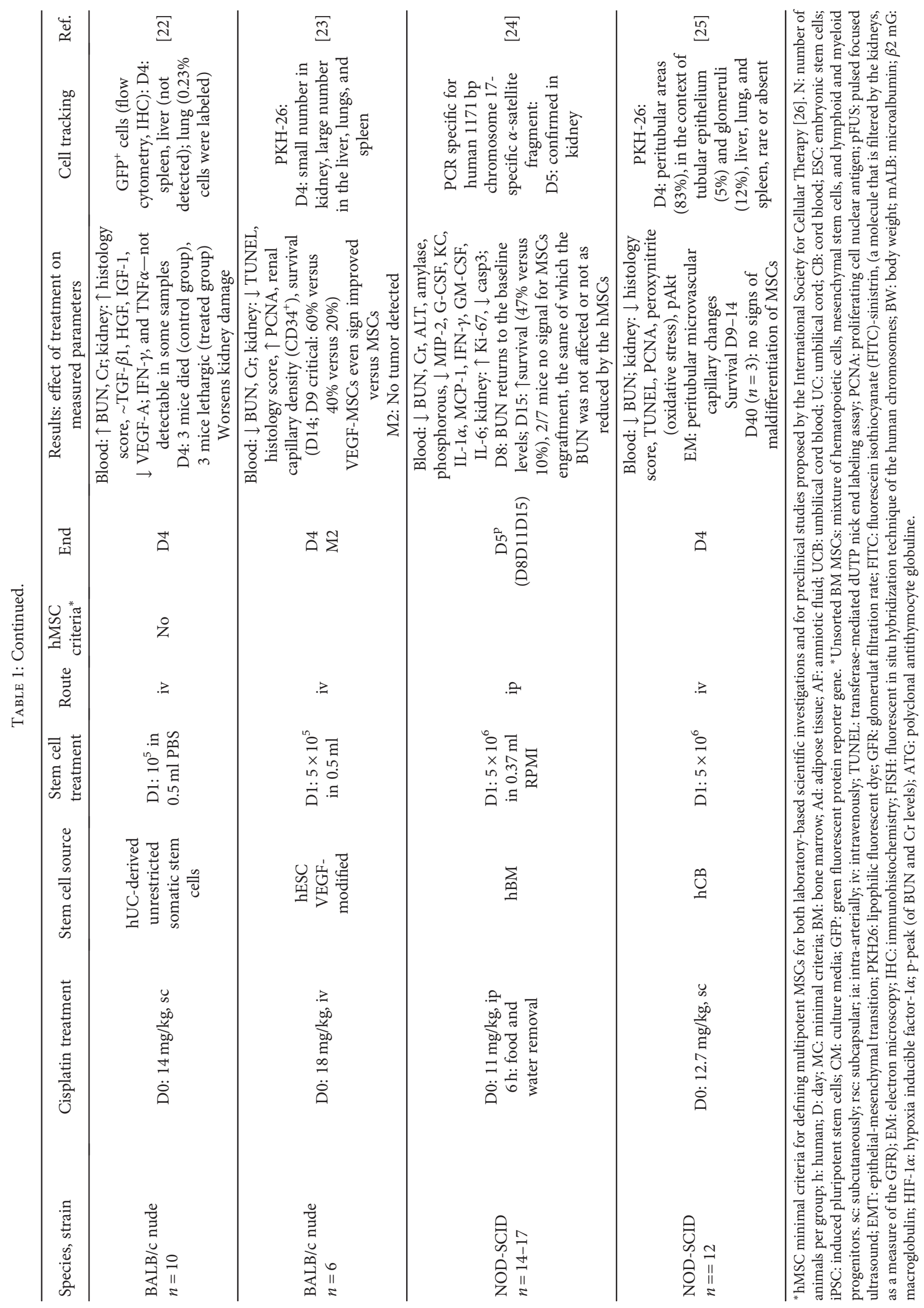




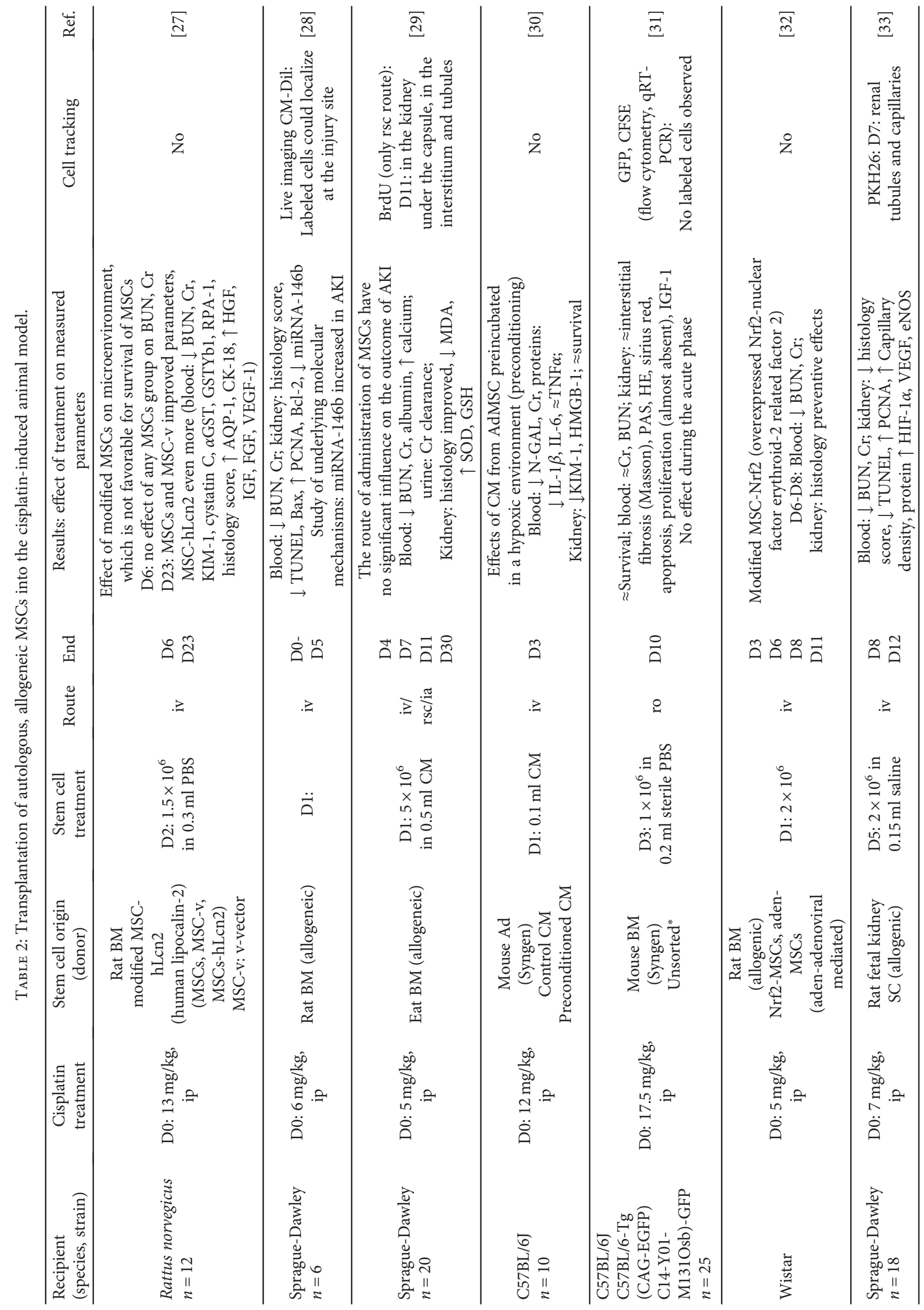




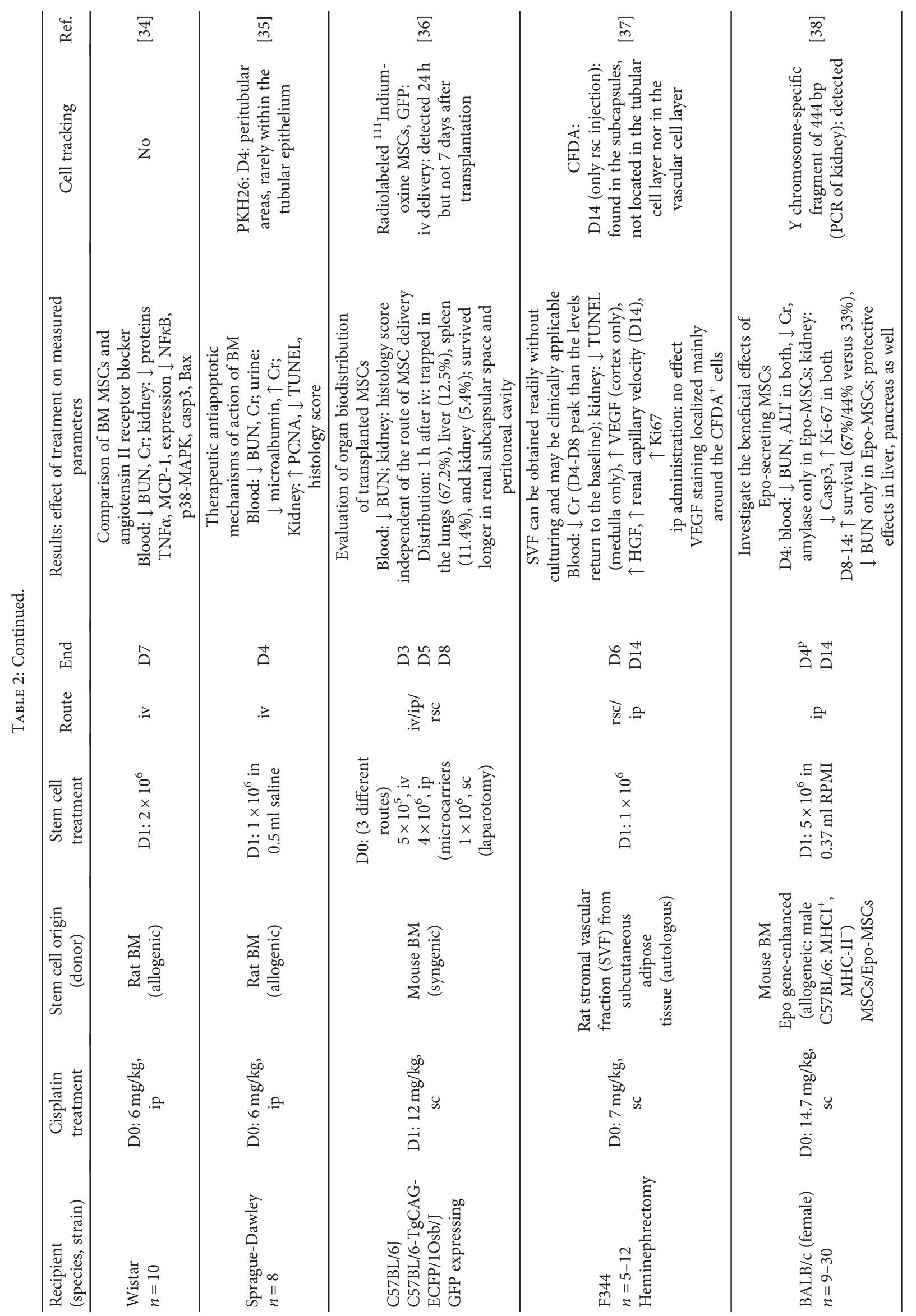




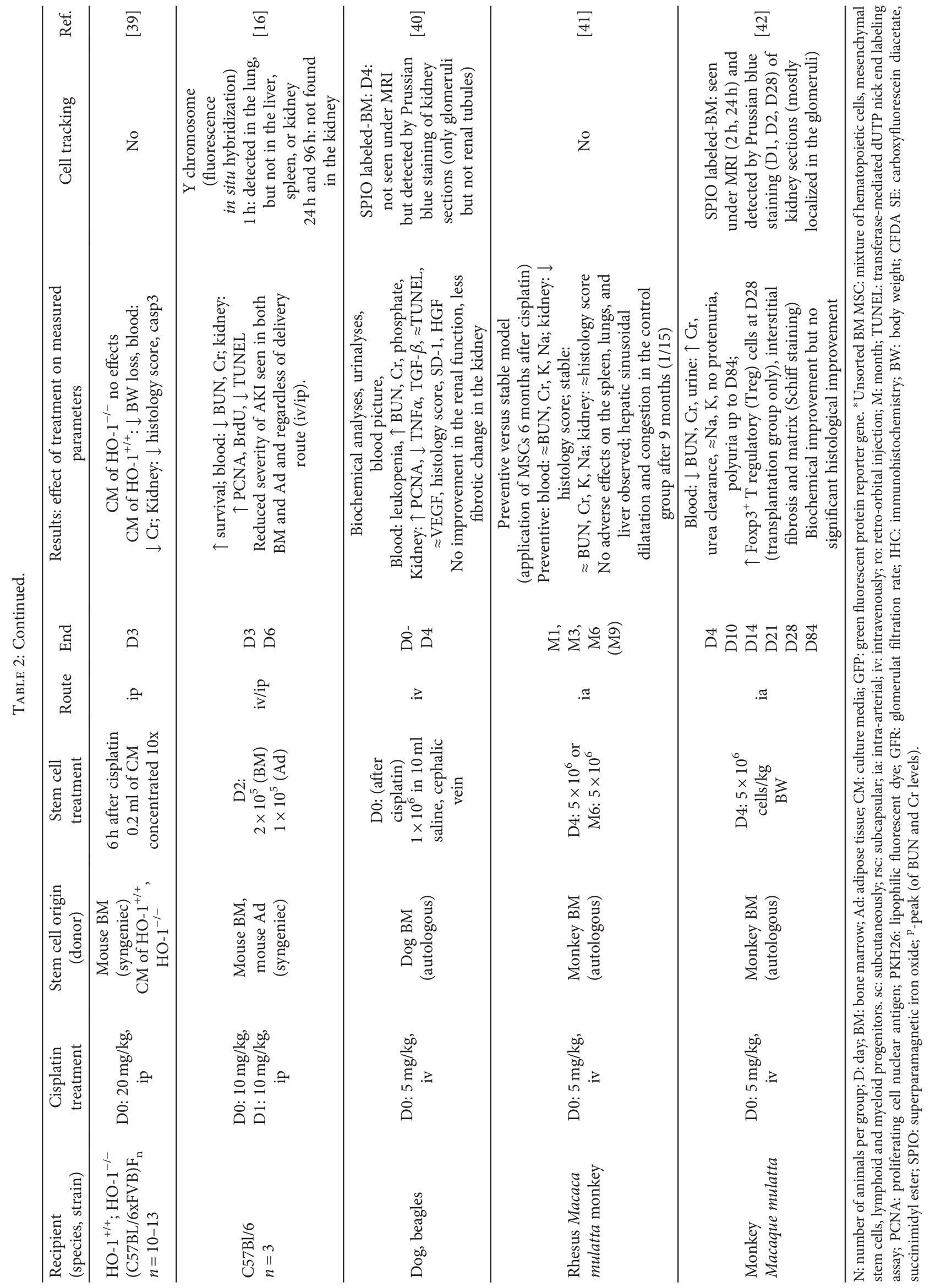


TABLE 3: The acute lethal single dose of cisplatin varies among various strains of mice and rats.

\begin{tabular}{|c|c|c|c|c|}
\hline Strain (origin), sex, age & Cisplatin dose & Mortality & Time & Ref. \\
\hline Wistar rats female & $10.8 \mathrm{mg} / \mathrm{kg}(9.1-12.8 \mathrm{mg} / \mathrm{kg})$ & $50 \%$ & D10 & {$[43]$} \\
\hline Fischer 344 rats female, 8 wks & $11 \mathrm{mg} / \mathrm{kg}$ & $50 \%$ & D6 & {$[44,45]$} \\
\hline $\begin{array}{l}\text { BALB/c (Harlan) } \\
\text { female }\end{array}$ & $14.5 \mathrm{mg} / \mathrm{kg}$ & $100 \%$ & D7 & {$[46,47]$} \\
\hline $\begin{array}{l}\text { C57BL/6 (Japan) } \\
\text { Male, } 11-15 \text { wks }\end{array}$ & $15 \mathrm{mg} / \mathrm{kg}$ & $100 \%$ & D10 & {$[48]$} \\
\hline Swiss Webster male & $\begin{array}{l}16.0 \pm 0.8 \\
19.5 . \pm 0.8\end{array}$ & $\begin{array}{l}50 \% \\
100 \%\end{array}$ & D10 & [49] \\
\hline C57BL/6 x DBA/2 (F1) male & $\begin{array}{l}10 \mathrm{mg} / \mathrm{kg} \\
14 \mathrm{mg} / \mathrm{kg}\end{array}$ & $\begin{array}{c}0 \% \\
90 \%\end{array}$ & D8 & {$[49]$} \\
\hline DBA2 mice female & $\begin{array}{c}10.7 \mathrm{mg} / \mathrm{kg} \\
16 \mathrm{mg} / \mathrm{kg}\end{array}$ & $\begin{array}{l}50 \% \\
90 \%\end{array}$ & $\begin{array}{l}\text { D10 } \\
\text { D30 }\end{array}$ & [43] \\
\hline $\begin{array}{l}\text { 129SV } \\
\text { Male, } 8-12 \text { wks }\end{array}$ & $14 \mathrm{mg} / \mathrm{kg}$ & $70 \%$ & D7 & {$[50]$} \\
\hline $\begin{array}{l}\text { CBA (UK) } \\
\text { Male, } 6 \text { wks }\end{array}$ & $\begin{array}{l}10 \mathrm{mg} / \mathrm{kg} \\
15 \mathrm{mg} / \mathrm{kg}\end{array}$ & $\begin{array}{c}0 \% \\
67 \%\end{array}$ & D15 & {$[51]$} \\
\hline $\begin{array}{l}\text { CBA mice } \\
\text { Female, } 4-8 \text { wks }\end{array}$ & $16 \mathrm{mg} / \mathrm{kg}$ & $40 \%$ & D8 & {$[52]$} \\
\hline $\begin{array}{l}\text { CBA mice } \\
\text { Female, } 24 \text { months }\end{array}$ & $16 \mathrm{mg} / \mathrm{kg}$ & $100 \%$ & D7 & [53] \\
\hline NMRI mice female & $17.0 \mathrm{mg} / \mathrm{kg}(14.9-19.7 \mathrm{mg} / \mathrm{kg})$ & $50 \%$ & D10 & {$[43]$} \\
\hline
\end{tabular}

D: days after cisplatin injection.

prevent rejection) or the recipient will need proper immunosuppressive therapy.

Short duration of studies (usually less than a week) and rare distribution of MSCs in the kidney sections (very small in number) suggest that the beneficial effect of MSCs cannot be attributed to their engraftment or transdifferentiation. Thus, recent studies have suggested that MSCs protect against acute tubular injury through a differentiationindependent process (i.e., paracrine or endocrine process). Consequently, it was suggested that if the cells merely transit through the kidney and act in a paracrine manner to protect or stimulate the endogenous renal cells, then they might only need to survive for a few days and immune environment may not be important [16]. However, recent studies show that the situation is not so simple as it was suggested.

First, acute rejection of injected cells in cisplatin model was not evaluated nor reported. It was only reported that cells disappeared within $24 \mathrm{~h}$ after injection [18, 22, 31], which could suggest acute rejection. However, sensitization reaction (mixed-lymphocyte reaction-MLR test) that could confirm or omit immune reaction was not done in any of AKI studies. Since most of the studies using a cisplatin animal model investigated effects of MSC transplantation ended within 4 days, the time period may be too short for the immune reaction evaluation. Nevertheless, until now, no MLR test or immune reaction in long-term studies on AKI was reported. However, we observed the immune reaction in immunocompetent mice 3 months after MSC treatment, although mice were immunosuppressed with polyclonal antithymocyte globuline (ATG) before MSC therapy (unpublished data). MSC treatment resulted in complete restitution of cisplatin- injured organs/tissue such as the thymus, spleen, and kidney, as well as white and red blood cells (Table 5).

However, histology revealed that the mouse had moderate chronic jejunitis (Figure $1(\mathrm{~d})$ ) and rare small lymphohistiocytic infiltrates in the kidneys located periglomerularly and perivascularly (Figure 1(b)) and a subpleural tumor $0.5 \mathrm{~mm}$ in diameter (Figure 1(a)). It is important to take into consideration that athymia is associated with profound immunodeficiency, but restitution of thymus leads to the improvement of the immune system [67]. Restitution of thymus integrity and function (which was in our case diminished following ATG and cisplatin treatment) was already described after MSC therapy [68]. Moderate chronic jejunitis and focal infiltration of mononuclear cells in lungs and kidneys found in the mouse after MSC therapy may suggest that immunoregulatory properties of transplanted MSCs together with timely vanishing effect of ATG-enabled immune system awakening and resulted in the occurrence of dispersed inflammatory changes. Thus, our case demonstrates that studying long-term MSC therapeutic effect in immunocompetent mice is challenging and may raise additional questions.

Furthermore, studies have shown that extracellular membrane vesicles (MVs) by themselves are capable of modulating $\mathrm{T}$ cell functions and repairing injured tissue. It was found that cytokine stimulus affects molecular mechanisms of MSCs and may have significant effects of the MV production. Kilpinen et al. [69] investigated the production of extracellular MVs from human umbilical cord blood- (UCB-) derived MSCs in the presence $\left(\mathrm{MV}_{\text {stim }}\right)$ or absence $\left(\mathrm{MV}_{\text {contr }}\right)$ of inflammatory stimulus (IFN- $\gamma$ ) and demonstrated that 
TABLE 4: Examples of immune reaction after xenogenic or allogeneic MSC transplantation.

\begin{tabular}{|c|c|c|c|}
\hline MSC origin & Recipient, route of transplantation & Adverse immune reaction & Ref. \\
\hline $\begin{array}{l}\text { Allogeneic } \\
\text { Ad or BM }\end{array}$ & $\begin{array}{l}\text { Healthy horses; intravenous injection, } \\
3 \text { times D0, D14, D28 }\end{array}$ & $\begin{array}{c}\text { Day 35: } \uparrow \text { circulating } \mathrm{CD}^{+} \mathrm{T} \text { cells after } \\
\text { multiple iv injections of BM MSCs }\end{array}$ & [6] \\
\hline Xenogeneic hBM & $\begin{array}{l}\text { Sprague-Dawley rats: } \\
\text { Intracardiac injection } \\
\text { (i) Immunocompetent } \\
\text { (ii) Immunosuppressed (tacrolimus) } \\
\text { (iii) RNU athymic rats }\end{array}$ & $\begin{array}{l}\uparrow \text { macrophages in myocardium of } \\
\text { immunocompetent rats from day } 2 \text { to day } 7 \text {; } \\
\text { MLR test (peripheral blood of rats mixed with } \\
1 \% \text { or } 10 \% \text { of MSCs) showed } \uparrow \text { lymphocyte } \\
\text { proliferation in SD rats previously exposed to MSCs }\end{array}$ & {$[62]$} \\
\hline $\begin{array}{l}\text { Xenogeneic } \\
\text { hESCs }\end{array}$ & Healthy mice, immunocompetent & $\begin{array}{c}\text { Infiltrates of T cells and macrophages around } \\
\text { injected MSCs; MSCs disappeared } 3 \text { days after } \\
\text { transplantation (acute rejection) }\end{array}$ & [58] \\
\hline $\begin{array}{l}\text { Xenogeneic } \\
\text { hBM }\end{array}$ & $\begin{array}{l}\text { Rats } \\
\text { Intracardiac injection } \\
\text { RNU athymic rats } \\
\text { RNU + tacrolimus } \\
\text { Fisher + tacrolimus } \\
\end{array}$ & $\begin{array}{c}\text { Cells were present } 6 \text { weeks after transplantation } \\
\text { in RNU rats with additional immunosuppression, } \\
\text { in RNU rats without additional immunosuppression } \\
\text { (tacrolimus) or in Fisher rats with immunosuppression } \\
\text { no surviving hMSCs were found }\end{array}$ & {$[63]$} \\
\hline $\begin{array}{l}\text { Allogeneic or syngeneic } \\
\text { BM MSCs }\end{array}$ & $\begin{array}{l}\text { Wistar and Lewis rats; } \\
\text { Intracardiac injection } \\
\text { immunocompetent }\end{array}$ & $\begin{array}{c}\text { Allogeneic MSCs caused T cell and B cell activation and } \\
\text { stimulated the humoral immune system to produce } \\
\text { antibodies against the allogeneic cells-function } \\
\text { was lost after } 5 \text { months }\end{array}$ & [64] \\
\hline $\begin{array}{l}\text { Allogeneic, syngeneic, } \\
\text { and third party } \\
\text { BM MSCs }\end{array}$ & $\begin{array}{l}\text { BALB/c or B } 6 \text { mice; } \\
\text { Sublethally irradiated mice } \\
\text { intravenous injection }\end{array}$ & $\begin{array}{l}\text { The addition of host (syngeneic) MSCs enhanced } \\
\text { engraftment, while the infusion of donor (allogeneic) } \\
\text { MSCs was associated with increased rejection of } \\
\text { allogeneic donor BM cells and induce a memory } \\
\text { T cell response. Third-party MSCs had a neutral } \\
\text { effect on engraftment. }\end{array}$ & {$[65]$} \\
\hline $\begin{array}{l}\text { Allogenic } \\
\text { donor/recipient MSCs }\end{array}$ & $\begin{array}{l}\text { Rats: Lewis (donor), ACI (recipients); } \\
\text { heart transplantation with or without } \\
\text { immunosuppression (CsA) }\end{array}$ & $\begin{array}{l}\text { Allogeneic MSCs did not prolong allograft survival. } \\
\text { Treatment with low-dose CsA and MSCs accelerate } \\
\text { allograft rejection in a rat heart transplant model }\end{array}$ & {$[66]$} \\
\hline
\end{tabular}

BM: bone marrow; Ad: adipose tissue; hESC: human embryonic stem cells; CsA: cyclosporine A; Third party: commercially available; MLR: mixed-lymphocyte reaction; RNU: Rowett nude rats (athymic with the genotype $\mathrm{rnu} / \mathrm{rnu}$ ).

TABLE 5: Body weight, relative weight of organs, and blood parameters in BALB/cOlaHsd mice 3 months after hMSC transplantation.

\begin{tabular}{lccc}
\hline Parameter & CIS & hMSCs & Healthy \\
\hline WBC $\left(10^{3} / \mathrm{mm}^{3}\right)$ & 8.1 & 10.9 & 10.1 \\
RBC $\left(10^{6} / \mathrm{mm}^{3}\right)$ & 7.46 & 10.35 & 9.46 \\
PLT $\left(10^{3} / \mathrm{mm}^{3}\right)$ & 1303 & 773 & 789 \\
Body weight $(\mathrm{g})$ & 23.7 & 31.4 & 31.6 \\
RW of the spleen & 0.877 & 0.42 & 0.35 \\
RW of the liver & 6.9 & 5.0 & 4.7 \\
RW of the kidney & 1.5 & 1.36 & 1.82 \\
RW of the lungs & 1.14 & 1.14 & 1.25 \\
RW of the heart & 0.96 & 0.67 & 0.59 \\
\hline
\end{tabular}

CIS: mice treated with ATG and cisplatin (ip, $17 \mathrm{mg} / \mathrm{kg}$ ); hMSCs: mice treated with ATG, cisplatin (ip, $17 \mathrm{mg} / \mathrm{kg}$ ), and hMSCs (iv, $0.5 \times 10^{5}$ cells in $0.2 \mathrm{ml}$ PBS); healthy: mice received PBS instead; WBC: white blood cells; RBC: red blood cells; PLT: platelets; RW: relative weight (weight of organ divided by body weight * 100 ).

MSC paracrine regulation is complex. Although both $\mathrm{MV}_{\text {stim }}$ and $\mathrm{MV}_{\text {contr }}$ showed similar $\mathrm{T}$ cell modulation activity in vitro, only $\mathrm{MV}_{\text {contr }}$ were able to protect rat kidney in vivo. Detailed analysis of MV proteomes revealed significant differences in protein composition of MVs in dependence of the microenvironment of MSCs. $\mathrm{MV}_{\text {contr }}$ contained complement factors (C3, C4A, and C5) and lipid binding proteins (i.e., apolipoproteins), whereas the $M V_{\text {stim }}$ contained tetraspanins (CD9, CD63, and CD81) and more complete proteasome complex accompanied with MHCI. IFN- $\gamma$ stimulation of MSCs for $24 \mathrm{~h}$ resulted in secretion of MVs that contained the HLA-A (MHCI) molecule and both $\alpha$ and $\beta$ units of the proteasome complex required for the antigen presentation and activation of $\mathrm{T}$ cells. When hUCB-MSCs were stimulated with IFN $\gamma$ for 48 hours, MVs contained also HLA-II proteins. Thus, inflammatory signals in the microenvironment can significantly influence not only MSCs but also the protein content and functional properties of secreted MVs [69]. These results represent additional challenge or consideration for future studies.

\section{What Are the Signs of Acute Cellular Rejection?}

Although numerous studies have demonstrated that MSCs show low level of immunogenicity and can have an immunomodulatory role [60], animal studies have demonstrated that xenogenic or allogeneic MSCs can trigger either acute cellular or humoral immune response or both. Differentiation of 


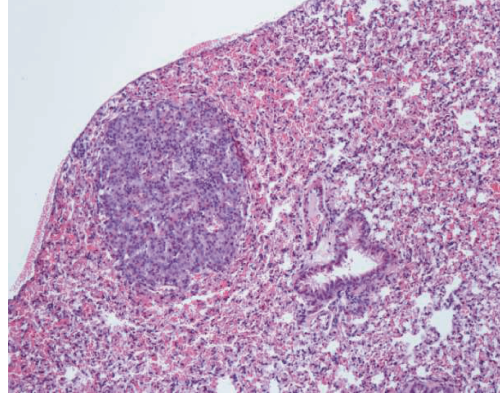

(a)

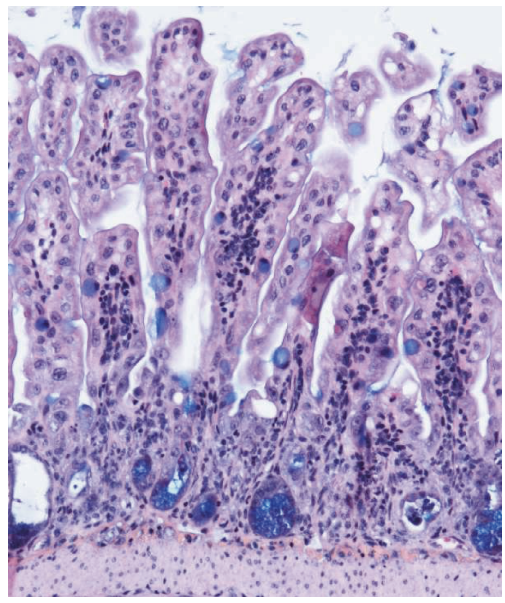

(d)

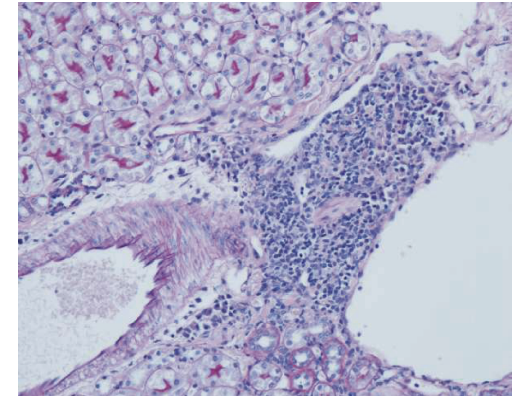

(b)

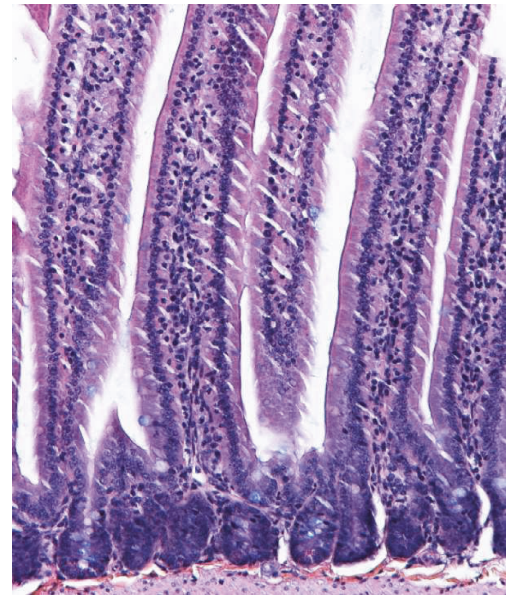

(e)

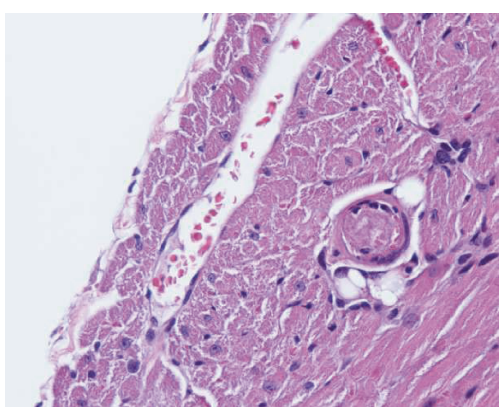

(c)

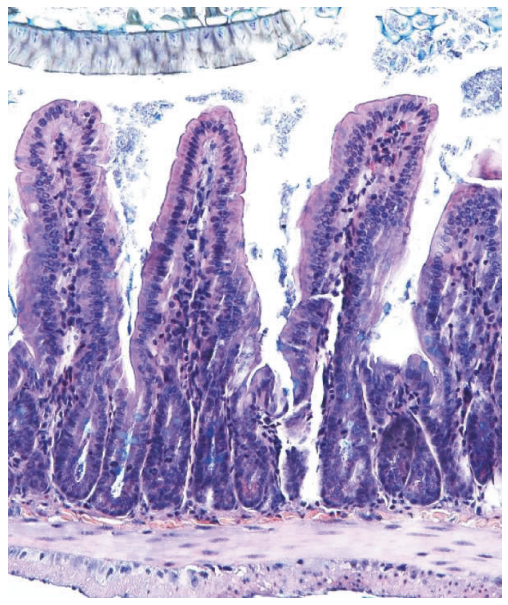

(f)

FIGURE 1: hMSC treatment in ATG immunosuppressed and cisplatin-treated BALB/cOlaHsd male mice 3 months after transplantation revealed unexpected pathology. (a) Subpleuraly, a homogeneous solid tumor (diameter $0.5 \mathrm{~mm}$ ) with rare mitosis and uniform nuclei was sharply demarcated from the surrounding tissue in the lung of hMSC treated mouse (HE, magnification 100x). (b) Inflammatory cells (lymphocytes, plasma cells, and histiocytes) surrounding the arteriola and vein in the kidney of the hMSC-treated mouse (PAS, magnification 200). (c) Thrombus in the small artery of the right ventricle wall of ATG + cisplatin-treated mouse (HE, magnification 400x). (d) Moderate chronic jejunitis in hMSC-treated mouse-note atrophy of crypts and loss of architecture of villi (Kreyberg, magnification 400x). (e) Jejunum in the healthy untreated mouse (Kreyberg, magnification 400x). (f) Jejunum of the cisplatin-treated mouse. Restitution of the mucosa is seen; however, the height of villi is decreased compared to healthy mice (Kreyberg, magnification 400x).

MSCs (to acquire myogenic, endothelial, or smooth muscle characteristics) is associated with increased MHC-Ia and MHC-II (immunogenic) expression and reduced $\mathrm{MCH}-\mathrm{Ib}$ (immunosuppressive) expression [70], which result in increased cytotoxicity in coculture with allogeneic leukocytes (acute rejection). Cells expressing MHC-Ia are usually eliminated by cytolysis, while the loss of MHC-Ib (which has been reported to suppress $\mathrm{CD}^{+} \mathrm{T}$ cell response) may result in reduced immunosuppressive effects. In animal studies, it is difficult to evaluate the signs of acute cellular rejection; thus, we stated some points that can help researchers to assess the immune reaction.

5.1. Beneficial or Absent Effect. The microenvironment of the damaged kidney tissue is not favorable for survival of MSCs. Cells are exposed to a hypoxic nutritionally poor environment, oxidative stress, and masses of cytotoxic factors leading to an inflammatory cytokine storm affecting the efficacy of MSC therapy. Various approaches have been investigated to help MSCs to cope/resist with the harmful microenvironment into which cells are transplanted $[19,23]$. Thus, the absence of the effect of MSCs could indicate damaging microenvironment [31], MSC inactivity due to cryopreservation [71], and finally cell rejection.

On the other hand, amelioration of kidney dysfunction after MSC injection does not indicate that MSCs are not immunogenic, because along with $\mathrm{T}$ cell and $\mathrm{B}$ cell activation differentiated MSCs can stimulate the humoral immune system to produce antibodies against the allogeneic/xenogeneic cells. A good example of late rejection is the study where allogeneic or syngeneic MSCs were implanted into the infarcted rat myocardium. MSCs (versus media) significantly improved ventricular function for at least 3 months after implantation. Allogeneic MSCs differentiated by about 2 weeks after implantation, but at 5 weeks, antibodies against differentiated allogeneic MSCs (but not syngeneic) were detected in the circulation of recipient animals, and allogeneic MSCs were eliminated from the heart. Interestingly, their functional benefits were lost within 5 months [64].

5.2. Presence/Absence of Injected Cells-Different Method of Identification. There are various methods and markers for tracking the injected cell. They all have advantages and limitations and no single method is $100 \%$ reliable. It has been 
already reported that PKH26 is not a reliable tracking agent. Also, Santeramo et al. have shown that human cells (labeled with PKH26 or GFP) injected in athymic rats can give different results [18]. $\mathrm{PKH} 26^{+}$cells were found in the kidney close to the tubular or interstitial cells and lungs even 14 days after iv injection, while $\mathrm{GFP}^{+}$cells were exclusively located in the lungs and had disappeared within $24 \mathrm{~h}$ after injection [18]. Obtained results confirmed that PKH26 is not a reliable tracking agent and explained the observed discrepancy among studies regarding the duration of homing of injected-labeled cells (as mentioned above in Section 3). It is important to be aware that when a labeled cell is phagocytosed by macrophages, the stain is usually not immediately degraded. Thus, the macrophage with phagocytosed fragments of labeled cells can give false positive results.

5.3. Presence of $T$ Cells and/or Macrophages around Cells-Acute Rejection. Infiltration of $\mathrm{T}$ cells and macrophages around transplanted cells is usually a sign of acute cellular rejection. It can be observed soon after transplantation and result in the disappearance of transplanted cells within a few days. In a cisplatin animal model, immune rejection of injected cells was not studied nor reported. Therefore, conclusions about immunogenic tolerance of MSCs cannot be made. Interestingly, although the authors of one study found that injected cells became entrapped in the lungs and cells and their fragments were then phagocytosed by resident macrophages $\left(\mathrm{CD}^{+} 8^{+}\right)$and dendritic cells within $24 \mathrm{~h}$ of administration, they observed the beneficial effect of injected cells on AKI [18] but did not report or mention possibility of potential acute rejection.

\section{Risk of Tumorigenicity}

Current knowledge about the risk of tumorigenicity in MSC therapy has been recently reviewed $[72,73]$. It was realized that currently there is not enough data/studies to make any conclusions. "In current animal models, in which either human or animal cells (homologous models) are used, no evidence of tumor formation has been observed to date. However, the frequency of transformation of human MSCs is too low to detect overt tumor formation in established rodent model" [72]. It was also stated that "it should be emphasized that tumor formation in human patients after MSC administration has not been reported to date" [72, 73].

However, several researchers have so far described the role of MSCs in tumor formation [74, 75] and some succeeding observations of malignant lesions in the fields of transplanted MSCs [76, 77] published after the review of Barkholt et al. [72] place a serious question on the former statements.

In our case, the tumor in the lungs of the mouse was observed 3 months after MSC therapy. Cisplatin-associated lung adenomas are among already observed late onset secondary tumors in experimental rodents treated with cisplatin $[56,78]$. In spite of large interspecies differences in the rates of metabolism of cisplatin, in the case of secondary solid tumors in humans (tumors that arise after treatment of primary malignancy as a consequence of cytostatic therapy), there is an average $20-40$ year expected interval from the time of exposure of an individual to a chemical carcinogen until the clinical detection of a tumor [79] that raises additional questions regarding possible tumor-promoting influence of stem cell therapy.

Another important issue to consider in the context of tumorigenicity is the convenience of systemic, that is, intravenous route of MSC infusion. It was reported that only a minority of intravenously infused MSCs reaches the target tissue and then disappears after few days (see Tables 1 and 2 and Section 3 and Section 5.2) [72]. Our results showed that intravenously infused human MSCs were mostly stuck in the liver and lungs of ATG immunosuppressed mice, only few of them reached other tissues including the kidneys and intestine after MSC infusion [80]. Although MSCs mediate their effects mostly through paracrine action, massive trapping of dead and/or dying MSCs in pulmonary or liver circulation after intravenous infusion may represent some burden for ill organism. It is also not known whether all MSCs that are trapped in the lungs either die or some of them are able to survive or even transform (under special circumstances).

Probably, the most important issue associated with tumorigenicity of transplanted MSCs in this experimental model is uremic and immunocompromised status of the host. While there is not much disagreement regarding the influence of manufacturing practice and in vitro culture conditions, especially the duration of cell propagation on chromosomal stability of the MSCs [72] and there is also no disagreement that the immunocompromised state is predisposed to malignancies [81, 82], it is still hypothetical whether the physiological stress associated with the in vivo diseased environment, that is, uremic could also promote tumorigenicity in MSCs. Transplanted MSCs are believed to be confronted with cell death within a few days after transplantation due to a combination of harsh environmental conditions, anoikis, and inflammation [83, 84]. However, if not all MSCs die after transplantation but few of them were able to successfully engraft, then the survivors' exposure time to uremic environment is markedly prolonged. In the in vitro conditions, uremic toxins impaired human bone marrow-derived mesenchymal stem cell functionality. The harm was surprisingly not proceeded via induction of apoptosis but by promoting damage to cell membranes and altering the MSCs paracrine activity [85]. A negative influence of uremic toxins on functional characteristics of MSCs raises concern on their possible role in promoting malignant transdifferentiation of MSCs, which should be further explored.

\section{Conclusion}

Although numerous studies have shown that MSC treatment ameliorated AKI, it is important to be aware that there are many factors to consider before any conclusion about the effectiveness or safety of MSC therapy can be made. One important factor is the cisplatin model itself, because cisplatin have short-term immunosuppressive and long-term carcinogenic effects. Another important factor is stem cell quality. We have found that only few researchers used hMSC that met the proposed criteria 
[26]. Third factor is immune microenvironment. Many researchers used immunodeficient animals. However, not all nude mice or rats are the same or have the same immunological state. Since only few stated the exact code of animals (according to Nomenclature http://www.informatics. jax.org/nomen/strains.shtml), obtained results cannot be properly interpreted and can be misleading. Since both MSC research and cisplatin models are very complex and their underlying mechanism possess many open questions, it is of great importance to design experiments properly and state all necessary data (in accordance with ARRIVE guidelines [86] and the gold standard publication checklist [87]) to contribute to responsible conduct of animal research and to validate the results. Otherwise, it can happen that this strategy, while seems to work experimentally, will fail when applied to patients.

\section{Conflicts of Interest}

The authors declare that no financial interest or conflicts of interests exist.

\section{Authors' Contributions}

Ž. Večerić-Haler and M. Perše contributed equally to this work.

\section{Acknowledgments}

This work was in part supported by the Slovenian Research Agency (ARRS) (Programs P3-054 and P3-0323).

\section{References}

[1] H. K. Lee, S. H. Lim, I. S. Chung et al., "Preclinical efficacy and mechanisms of mesenchymal stem cells in animal models of autoimmune diseases," Immune Network, vol. 14, no. 2, pp. 81-88, 2014.

[2] Y. Wang, J. He, X. Pei, and W. Zhao, "Systematic review and meta-analysis of mesenchymal stem/stromal cells therapy for impaired renal function in small animal models," Nephrology, vol. 18, no. 3, pp. 201-208, 2013.

[3] F. Casiraghi, N. Perico, M. Cortinovis, and G. Remuzzi, "Mesenchymal stromal cells in renal transplantation: opportunities and challenges," Nature Reviews Nephrology, vol. 12, no. 4, pp. 241-253, 2016.

[4] P. Lohan, C. M. Coleman, J. M. Murphy, M. D. Griffin, T. Ritter, and A. E. Ryan, "Changes in immunological profile of allogeneic mesenchymal stem cells after differentiation: should we be concerned?," Stem Cell Research \& Therapy, vol. 5, no. 4, p. 99, 2014.

[5] M. E. Reinders, G. J. Dreyer, J. R. Bank et al., "Safety of allogeneic bone marrow derived mesenchymal stromal cell therapy in renal transplant recipients: the neptune study," Journal of Translational Medicine, vol. 13, no. 1, p. 344, 2015.

[6] A. Kol, J. A. Wood, D. D. Carrade Holt et al., "Multiple intravenous injections of allogeneic equine mesenchymal stem cells do not induce a systemic inflammatory response but do alter lymphocyte subsets in healthy horses," Stem Cell Research \& Therapy, vol. 6, no. 1, p. 73, 2015.
[7] B. Wang, H. Jia, B. Zhang et al., "Pre-incubation with hucMSC-exosomes prevents cisplatin-induced nephrotoxicity by activating autophagy," Stem Cell Research \& Therapy, vol. 8, no. 1, p. 75, 2017.

[8] J. H. Park, H. R. Jang, D. H. Kim et al., "Early, but not late treatment with human umbilical cord blood-derived mesenchymal stem cells attenuates cisplatin nephrotoxicity through immunomodulation," American Journal of Physiology Renal Physiology, vol. 313, no. 4, pp. F984-F996, 2017.

[9] R. H. Ashour, M. A. Saad, M. A. Sobh et al., "Comparative study of allogenic and xenogeneic mesenchymal stem cells on cisplatin-induced acute kidney injury in SpragueDawley rats," Stem Cell Research \& Therapy, vol. 7, no. 1, p. 126, 2016.

[10] W. Yao, Q. Hu, Y. Ma et al., "Human adipose-derived mesenchymal stem cells repair cisplatin-induced acute kidney injury through antiapoptotic pathways," Experimental and Therapeutic Medicine, vol. 10, no. 2, pp. 468-476, 2015.

[11] S. R. Burks, B. A. Nguyen, P. A. Tebebi et al., "Pulsed focused ultrasound pretreatment improves mesenchymal stromal cell efficacy in preventing and rescuing established acute kidney injury in mice," Stem Cells, vol. 33, no. 4, pp. 1241-1253, 2015.

[12] R. H. Shalaby, L. A. Rashed, A. E. Ismaail, N. K. Madkour, and S. H. Elwakeel, "Hematopoietic stem cells derived from human umbilical cord ameliorate cisplatin-induced acute renal failure in rats," American Journal of Stem Cells, vol. 3, no. 2, pp. 83-96, 2014.

[13] X. Peng, H. Xu, Y. Zhou et al., "Human umbilical cord mesenchymal stem cells attenuate cisplatin-induced acute and chronic renal injury," Experimental Biology and Medicine, vol. 238, no. 8, pp. 960-970, 2013.

[14] J. Luo, X. Zhao, Z. Tan, Z. Su, F. Meng, and M. Zhang, "Mesenchymal-like progenitors derived from human embryonic stem cells promote recovery from acute kidney injury via paracrine actions," Cytotherapy, vol. 15, no. 6, pp. 649-662, 2013.

[15] J. H. Kim, D. J. Park, J. C. Yun et al., "Human adipose tissuederived mesenchymal stem cells protect kidneys from cisplatin nephrotoxicity in rats," American Journal of Physiology Renal Physiology, vol. 302, no. 9, pp. F1141-F1150, 2012.

[16] B. Bi, R. Schmitt, M. Israilova, H. Nishio, and L. G. Cantley, "Stromal cells protect against acute tubular injury via an endocrine effect," Journal of the American Society of Nephrology, vol. 18, no. 9, pp. 2486-2496, 2007.

[17] Y. Gheisari, N. Ahmadbeigi, M. Naderi, S. M. Nassiri, S. Nadri, and M. Soleimani, "Stem cell-conditioned medium does not protect against kidney failure," Cell Biology International, vol. 35, no. 3, pp. 209-213, 2011.

[18] I. Santeramo, Z. Herrera Perez, A. Illera et al., "Human kidneyderived cells ameliorate acute kidney injury without engrafting into renal tissue," Stem Cells Translational Medicine, vol. 6, no. 5, pp. 1373-1384, 2017.

[19] W. W. Wang, Z. Z. Li, W. Wang et al., "Enhanced renoprotective effect of HIF- $1 \alpha$ modified human adipose-derived stem cells on cisplatin-induced acute kidney injury in vivo," Scientific Reports, vol. 5, no. 1, article 10851, 2015.

[20] E. Papadimou, M. Morigi, P. Iatropoulos et al., "Direct reprogramming of human bone marrow stromal cells into functional renal cells using cell-free extracts," Stem Cell Reports, vol. 4, no. 4, pp. 685-698, 2015.

[21] B. Imberti, S. Tomasoni, O. Ciampi et al., "Renal progenitors derived from human iPSCs engraft and restore function in a 
mouse model of acute kidney injury," Scientific Reports, vol. 5, no. 1, p. 8826, 2015.

[22] Y. Gheisari, N. Ahmadbeigi, S. H. Aghaee-Bakhtiari et al., "Human unrestricted somatic stem cell administration fails to protect nude mice from cisplatin-induced acute kidney injury," Nephron Experimental Nephrology, vol. 123, no. 3-4, pp. 11-21, 2013.

[23] L. Yuan, M. J. Wu, H. Y. Sun et al., "VEGF-modified human embryonic mesenchymal stem cell implantation enhances protection against cisplatin-induced acute kidney injury," American Journal of Physiology Renal Physiology, vol. 300, no. 1, pp. F207-F218, 2011.

[24] N. Eliopoulos, J. Zhao, M. Bouchentouf et al., "Human marrow-derived mesenchymal stromal cells decrease cisplatin renotoxicity in vitro and in vivo and enhance survival of mice post-intraperitoneal injection," American Journal of Physiology Renal Physiology, vol. 299, no. 6, pp. F1288-F1298, 2010.

[25] M. Morigi, C. Rota, T. Montemurro et al., "Life-sparing effect of human cord blood-mesenchymal stem cells in experimental acute kidney injury," Stem Cells, vol. 28, no. 3, pp. 513-522, 2010.

[26] M. Dominici, K. Le Blanc, I. Mueller et al., "Minimal criteria for defining multipotent mesenchymal stromal cells. The International Society for Cellular Therapy position statement," Cytotherapy, vol. 8, no. 4, pp. 315-317, 2006.

[27] M. H. Roudkenar, R. Halabian, H. A. Tehrani et al., "Lipocalin 2 enhances mesenchymal stem cell-based cell therapy in acute kidney injury rat model," Cytotechnology, 2017.

[28] Y. Zhu, J. Yu, L. Yin et al., "MicroRNA-146b, a sensitive indicator of mesenchymal stem cell repair of acute renal injury," Stem Cells Translational Medicine, vol. 5, no. 10, pp. 1406-1415, 2016.

[29] F. E. Moustafa, M. A. Sobh, M. Abouelkheir, Y. Khater, K. Mahmoud, and M. A. Saad, "Study of the effect of route of administration of mesenchymal stem cells on cisplatininduced acute kidney injury in Sprague Dawley rats," International Journal of Stem Cells, vol. 9, no. 1, pp. 79-89, 2016.

[30] J. M. Overath, S. Gauer, N. Obermüller et al., "Short-term preconditioning enhances the therapeutic potential of adipose-derived stromal/stem cell-conditioned medium in cisplatin-induced acute kidney injury," Experimental Cell Research, vol. 342, no. 2, pp. 175-183, 2016.

[31] A. Bataille, P. Galichon, M. Wetzstein et al., "Evaluation of the ability of bone marrow derived cells to engraft the kidney and promote renal tubular regeneration in mice following exposure to cisplatin," Renal Failure, vol. 38, no. 4, pp. 521$529,2016$.

[32] M. Mohammadzadeh-Vardin, M. Habibi Roudkenar, and A. Jahanian-Najafabadi, "Adenovirus-mediated overexpression of Nrf2 within mesenchymal stem cells (MSCs) protected rats against acute kidney injury," Advanced Pharmaceutical Bulletin, vol. 5, no. 2, pp. 201-208, 2015.

[33] A. K. Gupta, S. H. Jadhav, N. K. Tripathy, and S. Nityanand, "Fetal kidney stem cells ameliorate cisplatin induced acute renal failure and promote renal angiogenesis," World Journal of Stem Cells, vol. 7, no. 4, pp. 776-788, 2015.

[34] I. O. Sherif, L. A. Al-Mutabagani, A. M. Alnakhli, M. A. Sobh, and H. E. Mohammed, "Renoprotective effects of angiotensin receptor blocker and stem cells in acute kidney injury: involvement of inflammatory and apoptotic markers," Experimental Biology and Medicine, vol. 240, no. 12, pp. 1572-1579, 2015.
[35] S. Qi and D. Wu, "Bone marrow-derived mesenchymal stem cells protect against cisplatin-induced acute kidney injury in rats by inhibiting cell apoptosis," International Journal of Molecular Medicine, vol. 32, no. 6, pp. 1262-1272, 2013.

[36] K. Cheng, P. Rai, A. Plagov et al., "Transplantation of bone marrow-derived MSCs improves cisplatinum-induced renal injury through paracrine mechanisms," Experimental and Molecular Pathology, vol. 94, no. 3, pp. 466-473, 2013.

[37] K. Yasuda, T. Ozaki, Y. Saka et al., "Autologous cell therapy for cisplatin-induced acute kidney injury by using non-expanded adipose tissue-derived cells," Cytotherapy, vol. 14, no. 9, pp. 1089-1100, 2012.

[38] N. Eliopoulos, J. Zhao, K. Forner, E. Birman, Y. K. Young, and M. Bouchentouf, "Erythropoietin gene-enhanced marrow mesenchymal stromal cells decrease cisplatin-induced kidney injury and improve survival of allogeneic mice," Molecular Therapy, vol. 19, no. 11, pp. 2072-2083, 2011.

[39] A. Zarjou, J. Kim, A. M. Traylor et al., "Paracrine effects of mesenchymal stem cells in cisplatin-induced renal injury require heme oxygenase-1," American Journal of Physiology Renal Physiology, vol. 300, no. 1, pp. F254-F262, 2011.

[40] C. Y. Lim, J. I. Han, S. G. Kim, C. M. Lee, and H. M. Park, "Evaluation of autologous bone marrow-derived mesenchymal stem cells on renal regeneration after experimentally induced acute kidney injury in dogs," American Journal of Veterinary Research, vol. 77, no. 2, pp. 208-217, 2016.

[41] R. Moghadasali, M. Hajinasrollah, H. Argani et al., "Autologous transplantation of mesenchymal stromal cells tends to prevent progress of interstitial fibrosis in a rhesus Macaca mulatta monkey model of chronic kidney disease," Cytotherapy, vol. 17, no. 11, pp. 1495-1505, 2015.

[42] R. Moghadasali, M. Azarnia, M. Hajinasrollah et al., "Intrarenal arterial injection of autologous bone marrow mesenchymal stromal cells ameliorates cisplatin-induced acute kidney injury in a rhesus Macaque mulatta monkey model," Cytotherapy, vol. 16, no. 6, pp. 734-749, 2014.

[43] T. Wagner, B. Kreft, G. Bohlmann, and G. Schwieder, "Effects of fosfomycin, mesna, and sodium thiosulfate on the toxicity and antitumor activity of cisplatin," Journal of Cancer Research and Clinical Oncology, vol. 114, no. 5, pp. 497-501, 1988.

[44] F. A. Levi, W. J. Hrushesky, F. Halberg, T. R. Langevin, E. Haus, and B. J. Kennedy, "Lethal nephrotoxicity and hematologic toxicity of cis-diamminedichloroplatinum ameliorated by optimal circadian timing and hydration," European Journal of Cancer \& Clinical Oncology, vol. 18, no. 5, pp. 471-477, 1982.

[45] W. J. Hrushesky, F. A. Levi, F. Halberg, and B. J. Kennedy, "Circadian stage dependence of cis-diamminedichloroplatinum lethal toxicity in rats," Cancer Research, vol. 42, no. 3, pp. 945-949, 1982.

[46] G. S. Baldew, C. J. van den Hamer, G. Los, N. P. Vermeulen, J. J. de Goeij, and J. G. McVie, "Selenium-induced protection against cis-diamminedichloroplatinum(II) nephrotoxicity in mice and rats," Cancer Research, vol. 49, no. 11, pp. 30203023, 1989.

[47] G. S. Baldew, J. G. McVie, M. A. van der Valk, G. Los, J. J. de Goeij, and N. P. Vermeulen, "Selective reduction of cisdiamminedichloroplatinum(II) nephrotoxicity by ebselen," Cancer Research, vol. 50, no. 21, pp. 7031-7036, 1990.

[48] T. Nakamura, A. Yonezawa, S. Hashimoto, T. Katsura, and K. Inui, "Disruption of multidrug and toxin extrusion MATE1 
potentiates cisplatin-induced nephrotoxicity," Biochemical Pharmacology, vol. 80, no. 11, pp. 1762-1767, 2010.

[49] D. L. Bodenner, P. C. Dedon, P. C. Keng, J. C. Katz, and R. F. Borch, "Selective protection against cis-diamminedichloroplatinum(II)-induced toxicity in kidney, gut, and bone marrow by diethyldithiocarbamate," Cancer Research, vol. 46, no. 6, pp. 2751-2755, 1986.

[50] H. Kawai, W. Sato, Y. Yuzawa et al., "Lack of the growth factor midkine enhances survival against cisplatin-induced renal damage," The American Journal of Pathology, vol. 165, no. 5, pp. 1603-1612, 2004.

[51] S. G. Allan, J. F. Smyth, F. G. Hay, R. C. Leonard, and C. R. Wolf, "Protective effect of sodium-2-mercaptoethanesulfonate on the gastrointestinal toxicity and lethality of cis-diamminedichloroplatinum," Cancer Research, vol. 46, no. 7, pp. 35693573, 1986.

[52] G. W. Hill, D. K. Morest, and K. Parham, "Cisplatin-Induced Ototoxicity," Otology \& Neurotology, vol. 29, no. 7, pp. 10051011, 2008.

[53] K. Parham, "Can intratympanic dexamethasone protect against cisplatin ototoxicity in mice with age-related hearing loss?," Otolaryngology and Head and Neck Surgery, vol. 145, no. 4, pp. 635-640, 2011.

[54] A. Naganuma, M. Satoh, and N. Imura, "Prevention of lethal and renal toxicity of cis-diamminedichloroplatinum(II) by induction of metallothionein synthesis without compromising its antitumor activity in mice," Cancer Research, vol. 47, no. 4, pp. 983-987, 1987.

[55] A. A. Al-Majed, M. M. Sayed-Ahmed, A. A. Al-Yahya, A. M. Aleisa, S. S. Al-Rejaie, and O. A. Al-Shabanah, "Propionyl-Lcarnitine prevents the progression of cisplatin-induced cardiomyopathy in a carnitine-depleted rat model," Pharmacological Research, vol. 53, no. 3, pp. 278-286, 2006.

[56] W. R. Leopold, E. C. Miller, and J. A. Miller, "Carcinogenicity of antitumor cis-platinum(II) coordination complexes in the mouse and rat," Cancer Research, vol. 39, no. 3, pp. 913918, 1979.

[57] K. Le Blanc, C. Tammik, K. Rosendahl, E. Zetterberg, and O. Ringdén, "HLA expression and immunologic properties of differentiated and undifferentiated mesenchymal stem cells," Experimental Hematology, vol. 31, no. 10, pp. 890-896, 2003.

[58] K. H. Grinnemo, M. Kumagai-Braesch, A. Månsson-Broberg et al., "Human embryonic stem cells are immunogenic in allogeneic and xenogeneic settings," Reproductive Biomedicine Online, vol. 13, no. 5, pp. 712-724, 2006.

[59] A. J. Poncelet, J. Vercruysse, A. Saliez, and P. Gianello, "Although pig allogeneic mesenchymal stem cells are not immunogenic in vitro, intracardiac injection elicits an immune response in vivo," Transplantation, vol. 83, no. 6 , pp. 783-790, 2007.

[60] T. Du and Y. J. Zhu, "The regulation of inflammatory mediators in acute kidney injury via exogenous mesenchymal stem cells," Mediators of Inflammation, vol. 2014, Article ID 261697, 11 pages, 2014.

[61] C. S. Lin, G. Lin, and T. F. Lue, "Allogeneic and xenogeneic transplantation of adipose-derived stem cells in immunocompetent recipients without immunosuppressants," Stem Cells and Development, vol. 21, no. 15, pp. 2770-2778, 2012.

[62] K. H. Grinnemo, A. Månsson, G. Dellgren et al., "Xenoreactivity and engraftment of human mesenchymal stem cells transplanted into infarcted rat myocardium," The Journal of Thoracic and Cardiovascular Surgery, vol. 127, no. 5, pp. 1293-1300, 2004.

[63] K. H. Grinnemo, A. Månsson-Broberg, K. Leblanc et al., "Human mesenchymal stem cells do not differentiate into cardiomyocytes in a cardiac ischemic xenomodel," Annals of Medicine, vol. 38, no. 2, pp. 144-153, 2006.

[64] X. P. Huang, Z. Sun, Y. Miyagi et al., "Differentiation of allogeneic mesenchymal stem cells induces immunogenicity and limits their long-term benefits for myocardial repair," Circulation, vol. 122, no. 23, pp. 2419-2429, 2010.

[65] A. J. Nauta, G. Westerhuis, A. B. Kruisselbrink, E. G. Lurvink, R. Willemze, and W. E. Fibbe, "Donor-derived mesenchymal stem cells are immunogenic in an allogeneic host and stimulate donor graft rejection in a nonmyeloablative setting," Blood, vol. 108, no. 6, pp. 2114-2120, 2006.

[66] S. Inoue, F. C. Popp, G. E. Koehl et al., "Immunomodulatory effects of mesenchymal stem cells in a rat organ transplant model," Transplantation, vol. 81, no. 11, pp. 1589-1595, 2006.

[67] Z. Zdrojewicz, E. Pachura, and P. Pachura, "The thymus: a forgotten, but very important organ," Advances in Clinical and Experimental Medicine, vol. 25, no. 2, pp. 369-375, 2016.

[68] G. Liu, L. Wang, T. Pang et al., "Umbilical cord-derived mesenchymal stem cells regulate thymic epithelial cell development and function in Foxn $1^{-} /^{-}$mice," Cellular \& Molecular Immunology, vol. 11, no. 3, pp. 275-284, 2014.

[69] L. Kilpinen, U. Impola, L. Sankkila et al., "Extracellular membrane vesicles from umbilical cord blood-derived MSC protect against ischemic acute kidney injury, a feature that is lost after inflammatory conditioning," Journal of Extracellular Vesicles, vol. 2, no. 1, 2013.

[70] A. Technau, K. Froelich, R. Hagen, and N. Kleinsasser, "Adipose tissue-derived stem cells show both immunogenic and immunosuppressive properties after chondrogenic differentiation," Cytotherapy, vol. 13, no. 3, pp. 310-317, 2011.

[71] R. Chinnadurai, M. A. Garcia, Y. Sakurai et al., "Actin cytoskeletal disruption following cryopreservation alters the biodistribution of human mesenchymal stromal cells in vivo," Stem Cell Reports, vol. 3, no. 1, pp. 60-72, 2014.

[72] L. Barkholt, E. Flory, V. Jekerle et al., "Risk of tumorigenicity in mesenchymal stromal cell-based therapies-bridging scientific observations and regulatory viewpoints," Cytotherapy, vol. 15, no. 7, pp. 753-759, 2013.

[73] F. Casiraghi, G. Remuzzi, M. Abbate, and N. Perico, "Multipotent mesenchymal stromal cell therapy and risk of malignancies," Stem Cell Reviews, vol. 9, no. 1, pp. 65-79, 2013.

[74] J. Houghton, C. Stoicov, S. Nomura et al., "Gastric cancer originating from bone marrow-derived cells," Science, vol. 306, no. 5701, pp. 1568-1571, 2004.

[75] A. B. Mohseny, K. Szuhai, S. Romeo et al., "Osteosarcoma originates from mesenchymal stem cells in consequence of aneuploidization and genomic loss of Cdkn2," The Journal of Pathology, vol. 219, no. 3, pp. 294-305, 2009.

[76] A. L. Berkowitz, M. B. Miller, S. A. Mir et al., "Glioproliferative lesion of the spinal cord as a complication of "stem-cell tourism"," The New England Journal of Medicine, vol. 375, no. 2, pp. 196-198, 2016.

[77] D. Thirabanjasak, K. Tantiwongse, and P. S. Thorner, "Angiomyeloproliferative lesions following autologous stem cell therapy," Journal of the American Society of Nephrology, vol. 21, no. 7, pp. 1218-1222, 2010. 
[78] L. B. Travis, R. E. Curtis, H. Storm et al., "Risk of second malignant neoplasms among long-term survivors of testicular cancer," Journal of the National Cancer Institute, vol. 89, no. 19, pp. 1429-1439, 1997.

[79] G. N. Wogan, S. S. Hecht, J. S. Felton, A. H. Conney, and L. A. Loeb, "Environmental and chemical carcinogenesis," Seminars in Cancer Biology, vol. 14, no. 6, pp. 473-486, 2004.

[80] Ž. Večerić-Haler, A. Erman, A. Cerar et al., "Improved protective effect of umbilical cord stem cell transplantation on cisplatin-induced kidney injury in mice pretreated with antithymocyte globulin," Stem Cells International, vol. 2016, Article ID 3585362, 12 pages, 2016.

[81] K. Katariya and R. J. Thurer, "Malignancies associated with the immunocompromised state," Chest Surgery Clinics of North America, vol. 9, pp. 63-77, 1999.

[82] R. J. Prestwich, F. Errington, P. Hatfield et al., "The immune system - is it relevant to cancer development, progression and treatment?," Clinical Oncology, vol. 20, no. 2, pp. 101$112,2008$.

[83] T. E. Robey, M. K. Saiget, H. Reinecke, and C. E. Murry, "Systems approaches to preventing transplanted cell death in cardiac repair," Journal of Molecular and Cellular Cardiology, vol. 45, no. 4, pp. 567-581, 2008.

[84] S. Lee, E. Choi, M. J. Cha, and K. C. Hwang, "Cell adhesion and long-term survival of transplanted mesenchymal stem cells: a prerequisite for cell therapy," Oxidative Medicine and Cellular Longevity, vol. 2015, Article ID 632902, 9 pages, 2015.

[85] M. Idziak, P. Pędzisz, A. Burdzińska, K. Gala, and L. Pączek, "Uremic toxins impair human bone marrow-derived mesenchymal stem cells functionality in vitro," Experimental and Toxicologic Pathology, vol. 66, no. 4, pp. 187-194, 2014.

[86] C. Kilkenny, W. J. Browne, I. C. Cuthill, M. Emerson, and D. G. Altman, "Improving bioscience research reporting: the ARRIVE guidelines for reporting animal research," PLOS Biology, vol. 8, no. 6, article e1000412, 2010.

[87] C. R. Hooijmans, M. Leenaars, and M. Ritskes-Hoitinga, "A gold standard publication checklist to improve the quality of animal studies, to fully integrate the Three Rs, and to make systematic reviews more feasible," Alternatives to Laboratory Animals, vol. 38, no. 2, pp. 167-182, 2010. 

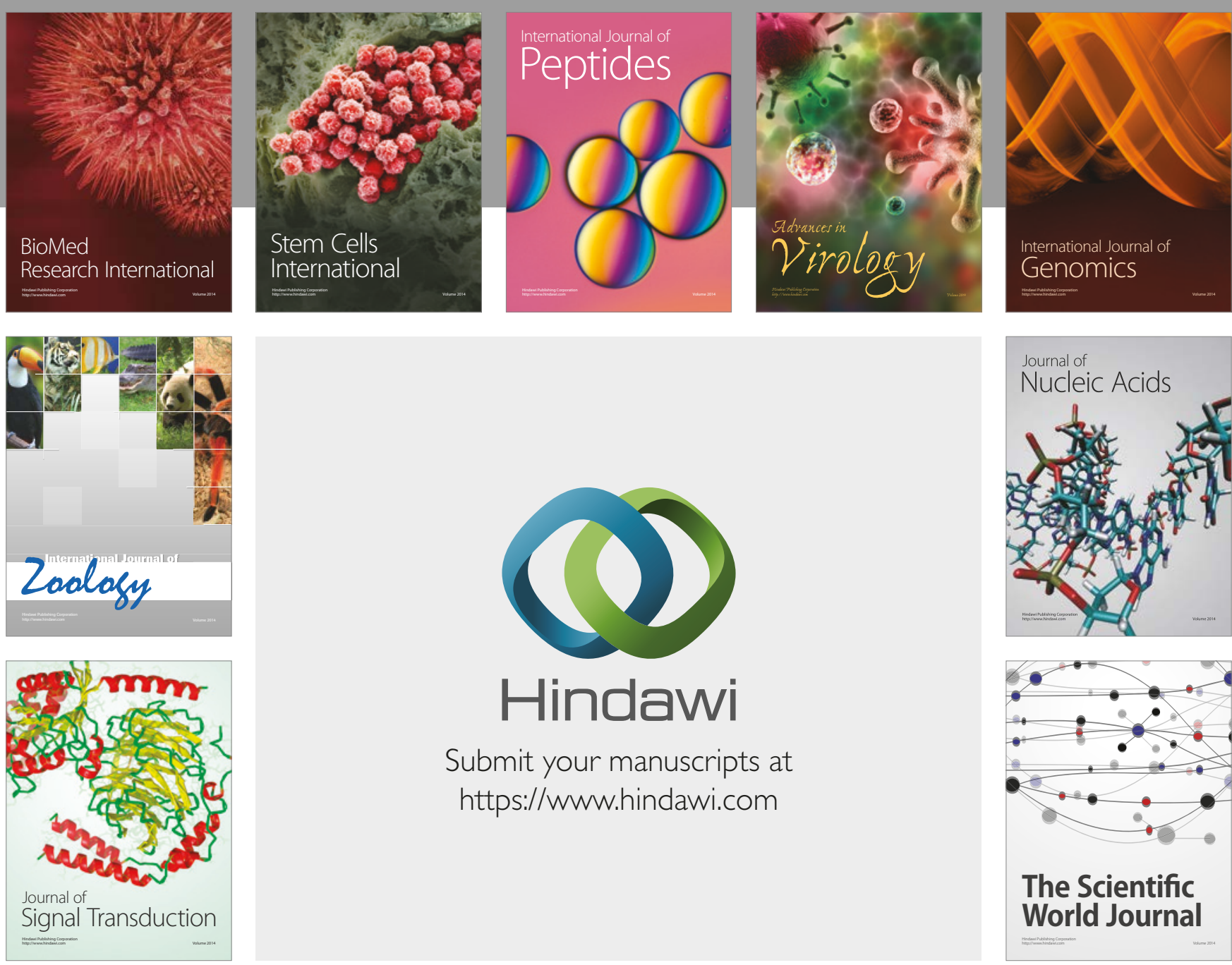

Submit your manuscripts at

https://www.hindawi.com
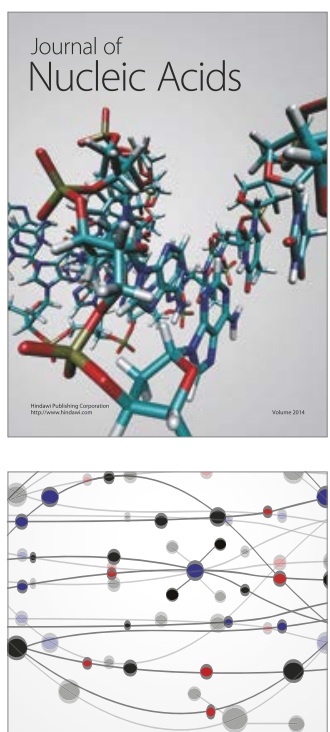

The Scientific World Journal

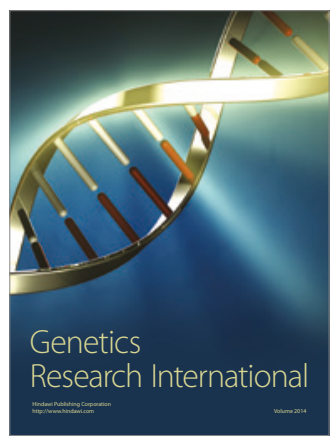

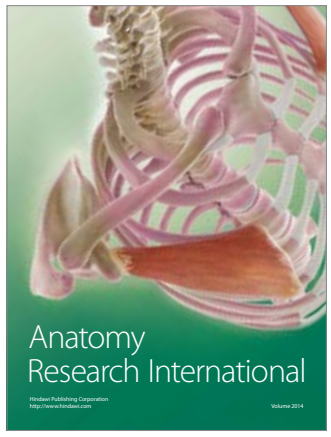

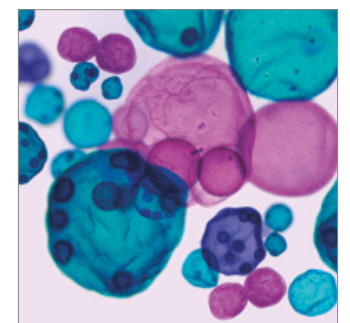

International Journal of Microbiology
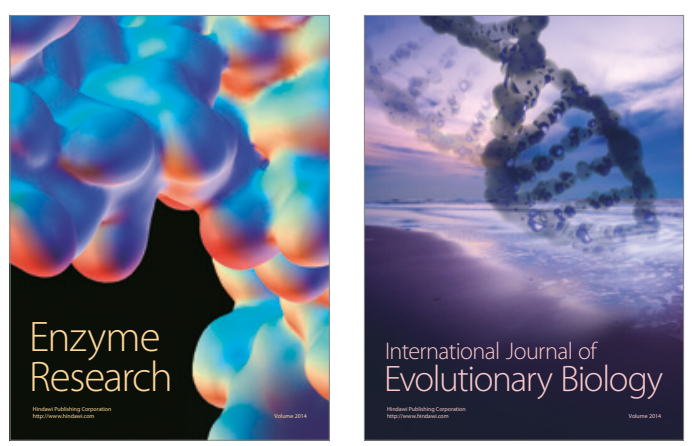
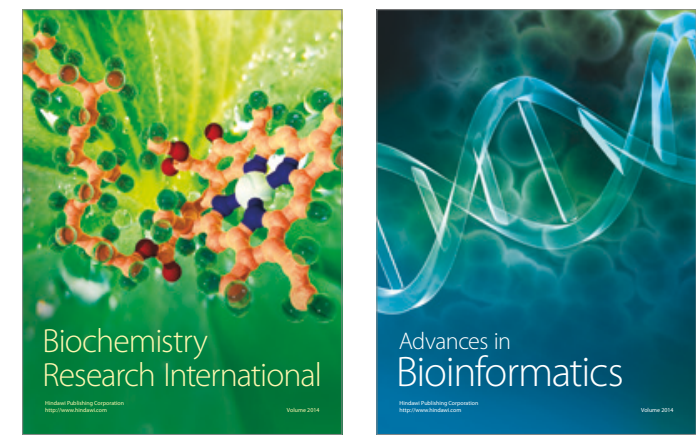

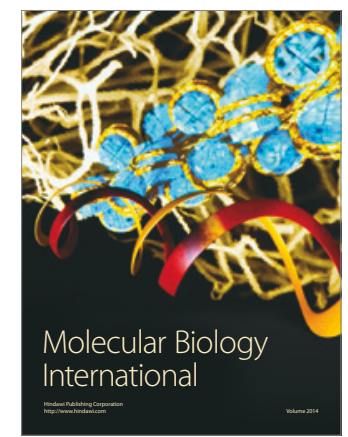

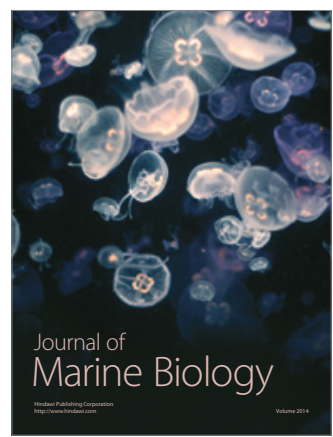

